\title{
CONFERENCE LETTERS
}

\section{Empower-SE COST Action International Research Workshop: Towards and enabling ecosystem for social enterprises}

\section{KEY-WORDS}

SOCIAL ENTERPRISE, STAKEHOLDERS, ECOSYSTEM

JEL Classification: A13, B55, L31, P13, O35 | DOI: http://dx.doi.org/10.5947/jeod.2020.004

The Research Workshop "Towards an enabling ecosystem for social enterprises", organized within the framework of the COST Action "Empowering the next generation of social enterprise scholars" (Empower-SE) ${ }^{1}$ was held at the University of Bucharest, Faculty of Sociology and Social Work in February $2020^{2}$. The event was built around research results produced under the COST Empower-SE Working Group 3 (WG3).

The main focus of WG3 is to encourage and support the development of a discussion forum among researchers and stakeholders from different countries, sharing the same interest in exploring and supporting social enterprises development. The aim of the workshop was to facilitate a vivid dialogue between stakeholders and researchers on the complex topic of social enterprise development and scaling. The specific objective of WP3 was to equip major social enterprises stakeholders with policy research information regarding the structure and evolution of social enterprise ecosystems.

\footnotetext{
http://www.empowerse.eu

2 EMPOWER-SE/1st WG3 Workshop, University of Bucharest (Romania), 12-13 February 2020.
} 
The program of the workshop scheduled in the first day a special introductory session, the "Stakeholders' Forum", followed by four parallel sessions involving researchers with different disciplinary perspectives on social enterprise ecosystems, and selected presenters of case studies. The second day was dedicated to a concluding plenary session and a special meeting of the COST Empower-SE Management Committee.

The Stakeholders' Forum gathered contributions from representatives of main social enterprises resource centres and networks, involved in social enterprises development in Romania: Ancuta Vamesu (Romanian Social Enterprises Network - RISE); Diana Chiriacescu (Federation of NGOs providing Social Services - FONSS); and Mihai Lisetchi (West University, Timisoara). The Stakeholders' Forum also envisaged a presentation of the European Commission perspective on social enterprise development, offered by Dana Verbal (Directorate-General for Employment, Social Affairs and Inclusion).

The social enterprise ecosystem in Romania was discussed in detail by major stakeholders involved in the developmental processes of the sector. They shared thoughts, concerns and vision of the future for social enterprises in Romania and other European Union (EU) Member States with the workshop participants. Stakeholders' interventions indicated that the social enterprise landscape in Romania has incrementally evolved since 2006. At present, the social enterprise population in the country is perplexing and dynamic, it includes both ex lege and de facto social enterprises, and both externally driven and bottom-up entities trying to subsist and develop within a challenging ecosystem.

From a historical perspective, Romanian social enterprises have multiple roots, which stem from cooperative and mutual aid society traditions. Key actors - such as associations and foundationshave significantly contributed to social enterprise development. The need for associations and foundations to pursue income-generating activities has enhanced their social missions and propelled them towards their institutionalization as social enterprises. Conversely, the Romanian "old" cooperative sector has remained relatively modest, making it one of the most disengaged stakeholders of the new social entrepreneurship reform. The panellists considered that the current narrative of social economy brings a new vision that could perhaps counteract the bad memories and mistrust from the past and fuel the development of social enterprises.

The Romanian panellists explained that the development of the social enterprise concept and practice in Romania is directly linked to the social economy framework. However, some confusion exists amongst policymakers, practitioners and the general public because social economy and social enterprise have been introduced as concepts in Romania almost simultaneously, after 2005. In addition, both concepts have been narrowly interpreted as a new way of approaching the social inclusion policy connected with EU funding. The accession of Romania to the EU in 2007 paved the way for a new policy approach regarding social economy, social entrepreneurship and the development of social enterprises, where mutual aid societies, associations, foundations and cooperatives could play a role in addressing key societal challenges and encountering unmet community needs. 
The panellists made extensive comments on the recent social enterprise institutionalization process. The Law on Social Economy, which acknowledges and regulates social enterprises, was only enacted in 2015. Law 219/2015 introduced the work-integration social enterprise (WISE) as a specific social enterprise category, which is identified as a "social insertion enterprise". Despite this advance, the legislation does not harness the full potential of social enterprises and its fiscal framework appears fragmented. As evaluated by the panellists, the law has had limited impact on the growth of the sector, and the implementation of public policies in support of traditional social economy entities or newly emerging social enterprises has been limited. Romanian WISEs integrate disadvantaged workers through economic activity as in other EU Member States; however, the Romanian government does not provide any subsidies on work contracts for disadvantaged workers employed by WISEs, nor does it fund the social services they provide. WISEs have to raise funds to cover these aspects of their operation.

Another largely discussed topic was related to the existence of exhaustive data on Romanian social enterprises. Data available are limited, as the categorization of social enterprises within statistical data is only a very recent development, since Law 219/2015 was introduced. In addition, only few organizations comply with certification requirements, largely because fiscal incentives remain limited and bureaucratic procedures are cumbersome.

Another topic tackled by panellists was related to the institutional environment in which social enterprises operate in Romania. Central and local governments, research and education institutions, social enterprise networks and coalitions, and other categories of stakeholders (e.g., media and the general public) are key actors in shaping the present and future of Romanian social enterprises and social entrepreneurship. Their level of understanding of what social enterprises can bring to Romanian society and their capacity to accommodate and translate their vision into an effective and sustainable policy framework are proving crucial for the success of social enterprises. Stakeholders' comments emphasized the relevant role of research and education in promoting the social enterprise concept. It was noted that EU-funded social economy and social enterprise research projects have multiplied since 2008. Equally, more investment has been forthcoming to develop Masters Programs and other academic courses for a new generation of social enterprise management specialists.

Within the Stakeholders' Forum, a comprehensive presentation was delivered by Dana Verbal, policy officer within the European Commission, on the evolution of the EU agenda. Her presentation focused on the Social Business Initiative (SBI) policy package that mainstreams social enterprises within an EU policy contex ${ }^{3}$. The presentation acknowledged the contribution of social enterprises to the EU policy objectives: inclusive job creation, better social cohesion, sustaining the fight against poverty and discrimination, a more entrepreneurial, inclusive and sustainable

For more information, see: https://ec.europa.eu/growth/sectors/social-economy/enterprises_en; https://www. fi-compass.eu/sites/default/files/publications/social-business-initiative-creating-a-favourable-climate-for-social-enterprises-key-stakeholders-in-the-social-economy-and-innovation.pdf 
economy, and the sustainability of welfare systems. Actions intended to improve access to financial support under the EU Employment and Social Innovation Programme (EaSI) and the European Fund for Strategic Investments (EFSI) were presented and widely discussed by participants. Much attention was given to the discussion of EU programs within the forthcoming 2021-2027 Multiannual Financial Framework. The continuity of policy support initiatives, better synergies between programs, more social enterprise visibility and better impact investment in the general EU policy action were particularly noted.

Following the Stakeholders' Forum, the first plenary session provided a general introduction on the social enterprise ecosystem topic. Hugo Pinto (University of Coimbra, Portugal) offered a general view on the ecosystem concept from a regional studies perspective. His presentation reviewed the main attributes of the ecosystem concept: participants' variety, systemic services, interdependence among ecosystem participants, non-contractual governance. Pinto also emphasized the conceptual fragmentation. The main focus of the presentation was related to the connections between the concept of social enterprise ecosystem and the concept of innovation. In his opinion, the establishing of a social innovation ecosystem requires a mode of governance that integrates actors from the civil society and the social, economic and academic field; social innovation hubs, labs and transfer centres, as intermediaries that accelerate social innovation activities; and the integration of different modes of innovation in transformational innovation strategies.

The following speaker Giulia Galera (Euricse, Italy) addressed the issue of social enterprise ecosystems in Europe in a comparative perspective. Galera made a detailed and comprehensive presentation of the generous scope of the study "Social Enterprises and their ecosystems in Europe" The study covered 35 countries, involved more than 70 researchers and more than 750 stakeholders. Her presentation offered an overview of the social enterprise situation across EU Member States, as reflected in the research reports. Each country is characterised by a specific ecosystem profile, generating a more or less enabling context for the development and scaling up of social enterprises ${ }^{5}$. The national ecosystem is shaped by a variety of factors as: the capacity of citizens' to self-organize; the degree of visibility and recognition enjoyed by social enterprises at different levels; their capacity to access different kind of resources (including resources for establishment and consolidation, resources for income-generating activities, repayable resources, tax breaks and fiscal benefits); the degree of development of the research exploring social enterprises from a national or comparative perspective, the existence of educational and skills development opportunities. In her presentation Galera highlighted that each element within a social enterprise ecosystem is interrelated and influenced

\footnotetext{
4 The study was conducted by Euricse (European Research Institute on Cooperative and Social Enterprises) and the EMES International Research Network and delivered 28 country reports (EU Member States), 7 country fiches (NonEU countries participating in the EaSI Programme) and a comparative synthesis report including the analysis of key factors explaining country commonalities and variations. The national reports and fiches are available at: https://europa. $\mathrm{eu} / \mathrm{dK} 34 \mathrm{uG}$
}

5 The national reports and fiches are available at: https://europa.eu/!dK34uG 
by the position and evolution of other actors within the same system. As a result, the decisions and strategic action of networks and coalitions, policymakers, the media, the general public, educators and researchers, the private sector and the EU as an external actor, all play a role in shaping the present and future social enterprise ecosystems. She summarized the findings of the comparative synthesis report starting with the presentation of main drivers and trends of social enterprises development in Europe and tackling each social enterprises development factor as identified in the research ${ }^{6}$. The comparative report shows the EU's growing demand for general interest services and an increase in the number of social enterprises thriving in response to varied sectorial openings. It also reveals that social enterprises are now better understood and legally recognized. Awareness of ethical businesses has particularly increased and is more in demand. Despite such positive factors, it is also acknowledged that social enterprises still have to overcome many challenges related to the need for improved conceptual clarity and better primary and secondary legislation, the untapped potential of cooperatives and the difficulties related to developing functional relationships with public authorities based on trust and the comprehensiveness of each partner's specificity and role.

The four parallel sessions covered each social enterprise development factors with in-depth analysis, provided from different disciplinary angles and from various national perspectives.

The first parallel session focused on the capacity to self-organize and envisaged the contribution of Claudia Petrescu (Research Institute for Quality of Life, Romania), Anna Ciepielewska (Polish Academy of Sciences), Vincent Caruana (University of Malta), Giorgia Trasciani (University of AixMarseille, France and University "L'Orientale" of Naples, Italy) and Anna Umanseva (Denmark). All panellists emphasized the importance of social enterprise umbrella organizations, networks and the role of citizens' participation in supporting the growth of social enterprises in different contexts. Petrescu presented the conclusions of a case study focusing on the Retirees' Mutual aid Association, a specific type of a de facto social enterprise having a spectacular development in the last 30 years in Romania. Ciepielewska moved the discussions on the importance of networks for the overall development of the social enterprises sector. The analysis covered the situation of social enterprise networks in Poland, were such support mechanisms are still in an incipient phase of development. Caruana discussed the importance of voluntary engagement in the diffusion of new social enterprises, focusing on the situation in Malta. Trasciani presented a case study of a successful social enterprise initiative covering the topic of asylum seekers reception services in Italy. Another case study was presented by Umanseva, who illustrated a social economy initiative in the agricultural sector.

Within the second parallel session, focused on the issue of social enterprise recognition and selfrecognition, the situation and impact of legal recognition of social enterprises was largely discussed. Silvia Ferreira (University of Coimbra, Portugal) addressed the issue of legal recognition in Portugal,

The comparative synthesis report is available at: https://ec.europa.eu/social/main.jsp?catId=738\&langId=en\&pubId $=8274 \&$ furtherPubs=yes 
followed by Lāsma Līcite (University of Latvia) which analysed the impact of the Law on Social Enterprise in her country. Michaela Gionvannini's (University of Coimbra, Portugal) presentation was focused on a comparative assessment of the self-recognition process in different countries. The panel included two case study presentations. The first presenter, Anto Jankovic (Montenegro), addressed the issue of social enterprises institutionalization in Montenegro, exploring the present landscape of the ecosystem. The second case study, presented by Tsvetelina Marinova (Bulgaria), covered the recently institutionalisation of social enterprises in Bulgaria, and provided insights on the evolutions within the ecosystem. The panellists and case study presenters emphasized the positive impact of legal recognition and the diversity of legal frameworks and legal arrangements available in their countries and the growing trend towards a more consistent self-recognition for different type of organizations operating as social enterprises. Better visibility and understanding of the specificity and role of social enterprises are positive factors enabling the institutionalization process and self-recognition process to develop.

The third parallel session focused on the access to resources, which is a crucial topic for social enterprises as well as for any other type of enterprise. The presentations covered both the issues of the demand for and the supply of resources, capturing the specificity and complexity of the access to resources for social enterprises. Carlo Borzaga (Euricse, Italy) discussed the access to financial resources for social enterprises in different EU Member States, based on the findings of the abovementioned study "Social Enterprises and their ecosystems in Europe". In his presentation, he made a classification of the diverse types of financial resources: non-repayable resources to start-up and scale, resources from income generating activities, repayable resources mainly used to finance investments and fiscal breaks, advantages and incentives. The following panellist, Melinda Mihaly (Leipzig University, Hungary) focused her presentation on the importance of EU funding in countries within Central and Eastern Europe (CEE) and Southeast Europe (SEE) regions. Fergus Lyon (Middlesex University, UK) delivered a presentation focusing on the complexity of social enterprise funding in the UK. The session also included three case studies presentations. Maia Giorbelidze (Georgia) presented the situation of private capital used in support of social enterprise development in Georgia. Marianne Degevos (Netherlands) commented on the complexity of the ecosystem and the access to resources for social enterprises in The Netherlands. Cristina Dumitrescu (Romania) illustrated a case study on the EU Employment and Social Innovation (EaSI) Programme, which envisages the setting-up of financial mechanism specifically dedicated to social enterprises, which envisage mainly repayable financial instruments (loans and equity) but also grants and technical assistance to support the capacity of finance providers as well the capacity of social enterprises to access them.

The last parallel session covered the topic of research, education and skills development. The discussions underlined the observed increase in research and training related to social enterprise across countries, as well as the emergence of programs and tools in support of practitioners and different categories of stakeholders with an interest in social enterprise development. Research 
was identified as a key factor for the institutionalization and recognition of social enterprises. The first panellist, Rocío Nogales (EMES International Research Network) shared with the audience some reflections on the evolution of social enterprise research in Europe, identifying the main current research themes and critical issues to be put on the future research agenda. The following panellist, Lars Hulgard (Roskilde University, Denmark) proposed a reflection on the theme of skills development in the area of social enterprise and social entrepreneurship. He explored the role of education and skills development for the building-up of an enabling ecosystem. Millan DiazFoncea (Spain) proposed the analysis of a case study on the Social Economy Lab (LAB_ES), created in the Faculty of Economics and Business of the University of Zaragoza in 2017. An additional case study was presented by Abel Alan Diaz (Belgium) and illustrated the VUB Social Entrepreneurship Platform, promoted by the Vrije Brussel University with the aim of supporting social entrepreneurs.

In conclusion, the Research Workshop "Towards and enabling ecosystem for social enterprises" offered a wide space for in-depth discussions from various angles and contexts, gathering researchers and social enterprise stakeholders participating and modelling the complex social enterprise ecosystem, both at country level and at EU level. The panellists' papers and the case study presentations offered a complex image of country and regional variations of social enterprise ecosystems in Europe generated by the historical and cultural backgrounds, the degree of institutionalization and the specificity of the policy and political context for social enterprises. 